\title{
KINETICS OF THE SPONTANEOUS DISSOLUTION OF IRON IN CONCENTRATED IONIC MEDIA*
}

\author{
J. J. Podestát and A. J. ARvía \\ Instituto Superior de Investigaciones, Facultad de Química y Farmacia and División Ingeniería \\ Química, Facultad de Ciencias Fisicomatemáticas, Universidad Nacional de La Plata, \\ La Plata, Argentina
}

\begin{abstract}
The kinetics of the dissolution of polycrystalline iron in acid solutions has been studied. Perchloric acid in sodium perchlorate, hydrochloric acid in sodium chloride and nitric acid in sodium nitrate solutions were used, covering the range of $\mathrm{pH}$ between 0 and 6 at temperatures from 40 to $70^{\circ} \mathrm{C}$.

The rate of dissolution was followed by recording the activity of hydrogen ion in the solution, the corrosion potential being constant during the run.

The kinetic constant for hydrogen-ion disappearance was used to calculate the corrosion currentdensity assuming that hydrogen-ion discharge on an iron surface follows a Tafel equation with a slope of $2 \cdot 3(2 R T / F)$. For sodium perchlorate solutions the corrosion current increases with $\mathrm{pH}$ (in the range 1-5) with $\partial \log i_{\mathrm{corr}} / \partial \mathrm{pH}=-1$. For sodium chloride solutions the slope is close to -0.50 .

In the same range of $\mathrm{pH}$ the corrosion rate is greater in the order $\mathrm{ClO}_{4}^{-}, \mathrm{Cl}^{-}, \mathrm{NO}_{2}^{-}$. The results are interpreted in terms of recent information about the kinetics of the iron electrode.
\end{abstract}

Résumé-Etude, par enregistrement de la variation d'activité de $\mathrm{H}^{+}$, de la cinétique de dissolution de $\mathrm{Fe}$ polycristallin dans des solutions acides $\mathrm{HClO}_{4}+\mathrm{NaClO}_{4} ; \mathrm{HCl}+\mathrm{NaCl} ; \mathrm{HNO}_{3}+\mathrm{NaNO}_{3}$, de $\mathrm{pH} 1$ à 5 et de température 40 à $70^{\circ} \mathrm{C}$. La constante de vitesse peut servir au calcul de la densité du courant de corrosion, en supposant que la loi de Tafel, avec une pente $2,3(2 R T / F)$, gouverne la décharge d' $\mathrm{H}^{+}$sur $\mathrm{Fe}$. Avec les solutions de perchlorate (de $\mathrm{pH} 1 \mathrm{à} 5$ ), $\partial \log i_{\mathrm{corr}} / \partial \mathrm{pH}=1$; avec les solutions de chlorures, cette pente est voisine de $-0,5$. Le taux de corrosion croît dans l'ordre $\mathrm{ClO}_{4}^{-}, \mathrm{Cl}^{-}, \mathrm{NO}_{3}^{-}$et l'on interprète ces résultáts d'après des information récentes sur la cinétique de l'électrode de fer.

Zusammenfassung-Es wurde die Kinetik der Auflösung von polykristallinem Eisen in Säurelösungen untersucht. Lösungen, enthaltend Natriumperchlorat in Perchlorsäure, Natriumchlorid in Salzsäure und Natriumnitrat in Salpetersäure, wurden im pH-Bereich zwischen 1 und 5 und bei Temperaturen von 40 bis $70^{\circ} \mathrm{C}$ verwendet.

Die Aufiösungsgeschwindigkeit wurde bei konstantgehaltenem Korrosionspotential mittels Messung der Wasserstoffionen-Aktivität verfolgt. Die so ermittelte Geschwindigkeitskonstante des Wasserstoffionen-Verbrauchs diente zur Berechnung der Korrosionsstromdichten, indem vorausgesetzt wurde, dass die Wasserstoffabscheidung an Eisen einer Tafel-Geraden mit der Steigung $2,3(2 R T / F)$ gehorcht.

In den Natriumperchlorat-Lösungen erhöht sich der Korrosionsstrom mit steigenden $\mathrm{pH}$ nach $\partial \log i_{\text {corr }} / \partial \mathrm{pH}=-1$. In den Natriumchlorid-Lösungen liegt dieser Wert nahe bei $-0,5$. Im untersuchten $\mathrm{pH}$-Bereich nimmt die Korrosionsgeschwindigkeit in der Reihenfolge $\mathrm{ClO}_{4}^{-}, \mathrm{Cl}^{-}, \mathrm{NO}_{3}^{-}$ zu. Die Resultate werden im Lichte der neuesten Erkenntnisse über die Kinetik der Eisenelektrode interpretiert.

\section{INTRODUCTION}

Although the literature about iron dissolution is large indeed, a great deal of it is mainly concerned either with the anodic dissolution of the metal under an applied potential difference or with the spontaneous dissolution of impure specimens with the aim of obtaining practical data for particular systems.

We were interested in investigating the spontaneous dissolution of pure iron samples in solutions of known ionic strengths maintained practically constant during each experiment. The metal was therefore dissolved at its corrosion potential.

The study of the kinetics of the reaction was attempted by following the variation

* Manuscript received 26 April 1964.

† Present address: Department of Metallurgy, University of Cambridge, England. 
of hydrogen-ion activity of the medium potentiometrically by means of a glass electrode. We consider this technique reliable because the activity of hydrogen ion can be measured with good sensitivity; and great changes in the composition of the solution owing to a large amount of dissolved metal are avoided. On the other hand, since the corrosion rate depends on hydrogen-ion activity, the variation of the latter could be limited to a small range, and its influence actually evaluated.

Description of the cell

\section{EXPERIMENTAL}

A double-wall, round-bottom Pyrex glass cell of $400 \mathrm{~cm}^{3}$ was used. A Lucite cover was placed on top, to hold the metal electrode and other electrodes. A U-shaped tube dipped into the solution, with sintered glass at the end, was used to saturate the solution with purified inert gas. The cell was kept at a constant temperature of $\pm 0.05^{\circ} \mathrm{C}$.

Merck-Darmstadt iron wire, p.a. quality, $0.57 \mathrm{~mm}$ dia. and $9.5 \mathrm{~cm}$ long, was inserted into a small Teflon cylinder which was attached to the end of a tube allowing electrical contact.

Two saturated calomel electrodes (sce) were employed for the determination of both the hydrogen-ion activity and the corrosion potential of the metal, for the former purpose in conjunction with a glass electrode (ge). Both electrodes were placed in glass sleeves ending in S-shape capillary tips. In each run the sleeves were filled with the same solution, thus preventing any diffusion of chloride ion from the reference electrodes to the bulk of the solution.

E.I.L. GHS 23 glass electrodes were used, conveniently protected and calibrated with buffer solutions in the range of $\mathrm{pH}$, ionic strength, and temperature required by each of the experiments.

The iron samples were degreased with chloroform, washed first with ethyl alcohol, then repeatedly with twice distilled water and finally dipped into a solution having the same composition as that to be used later in the experiments. They were kept under a purified nitrogen atmosphere.

\section{Measuring devices}

A Radiometer PH 4 potentiometer was employed to determine the emf of the ge/sec couple. The corrosion potential of the iron was determined vs sce and continuously recorded with a Sargent potentiometric recorder.

Occasionally a constant velocity controlled stirrer was also used to demonstrate the existence of participation of diffusion processes in the dissolution reaction.

\section{Chemicals and solutions}

Sodium perchlorate was prepared by neutralizing Merck sodium hydroxide with a slight excess of AR perchloric acid. A $2 \mathrm{M}$ solution was obtained.

Ferrous perchlorate from Frederick Smith Chemical Co. was used. It gave a positive test for $\mathrm{Fe}$ (III), so it was reduced by treating a $0.1 \mathrm{M}$ solution with a small amount of Mallinckrodt pure iron powder and a slight excess of perchloric acid. The solution, filtered in an inert atmosphere, then gave a negative test for $\mathrm{Fe}$ (III).

AR sodium nitrate and nitric acid were used to prepare $2 \mathrm{M}$ stock solutions of the former at different $\mathrm{pH}$. Solutions were prepared with twice distilled water free 
from air and carbon dioxide, and saturated with nitrogen, which was purified in the usual way.

\section{Procedure}

In preliminary experiments the iron sample was rotated in the solution at a constant speed up to $1200 \mathrm{rpm}$, no definite effect of the stirring rate being observed when samples were rotated above $50 \mathrm{rpm}$. The same result was observed when the metal was placed on the gas diffuser included in the cell. The reaction course could be followed either by evaluation of the ferrous ion concentration in a portion of the solution or by determining the variation of the hydrogen-ion activity, without changing the total volume of the system. Although both methods yielded coincident values of the reaction rate, the latter was preferred because of the clearer technique involved.

Ionic media of sodium perchlorate, sodium chloride and sodium nitrate covering concentrations from 0.02 up to $2 \mathrm{M}$ were employed. Hydrogen-ion concentration was changed by adding quantities of the respective acid. pH was varied from 0 to 6 , but most of the experimental results were obtained in the $\mathrm{pH}$ range $1-4$, the region where hydrolysis of ferrous ion takes place being thus avoided. The experimental technique allowed us to follow the reaction when known amounts of ferrous ion were added to the solution.

\section{RESULTS AND INTERPRETATION}

\section{The specific rate constant}

Experimental results were obtained at temperatures between 40 to $70^{\circ} \mathrm{C}$. In this range of temperature the reaction was followed without any interference; the $\mathrm{pH}$ change of the solution during each run was not greater than $0 \cdot 3$ unit. In the course of an experiment the surface of the metal was not appreciably modified.

In Figs. 1-5 some experimental data of individual runs are shown. The hydrogenion disappearance both as a function of time in a small range of $\mathrm{pH}$ and under different experimental conditions can be observed.

The specific kinetic constant has been calculated on the basis of a first-order rate equation. The kinetic constant is referred to unit apparent area of the metal and unit volume of the solution employed.

Within the experimental error the kinetic constant shows no appreciable dependence on the concentration of the main electrolyte in the ranges of concentrations used. The ferrous ion concentration has no detectable effect on the rate constant for hydrogen-ion disappearance.

\section{The corrosion potential}

It is well known that the corrosion potential, $E$, depends linearly on $\mathrm{pH}$ and becomes more negative as the $\mathrm{pH}$ increases. The slope of the straight line of $E v s \mathrm{pH}$ observed by different authors is between 50 and $63 \mathrm{mV}$. Our experimental results for both perchlorate and chloride solutions give a slope of $62 \pm 3 \mathrm{mV}$ at $50^{\circ} \mathrm{C}$, as shown in Fig. 5. The linear relationship is obeyed up to a $\mathrm{pH}$ of approximately 5 . The corrosion potential was determined for each experiment and it was constant during the whole duration of the run. 


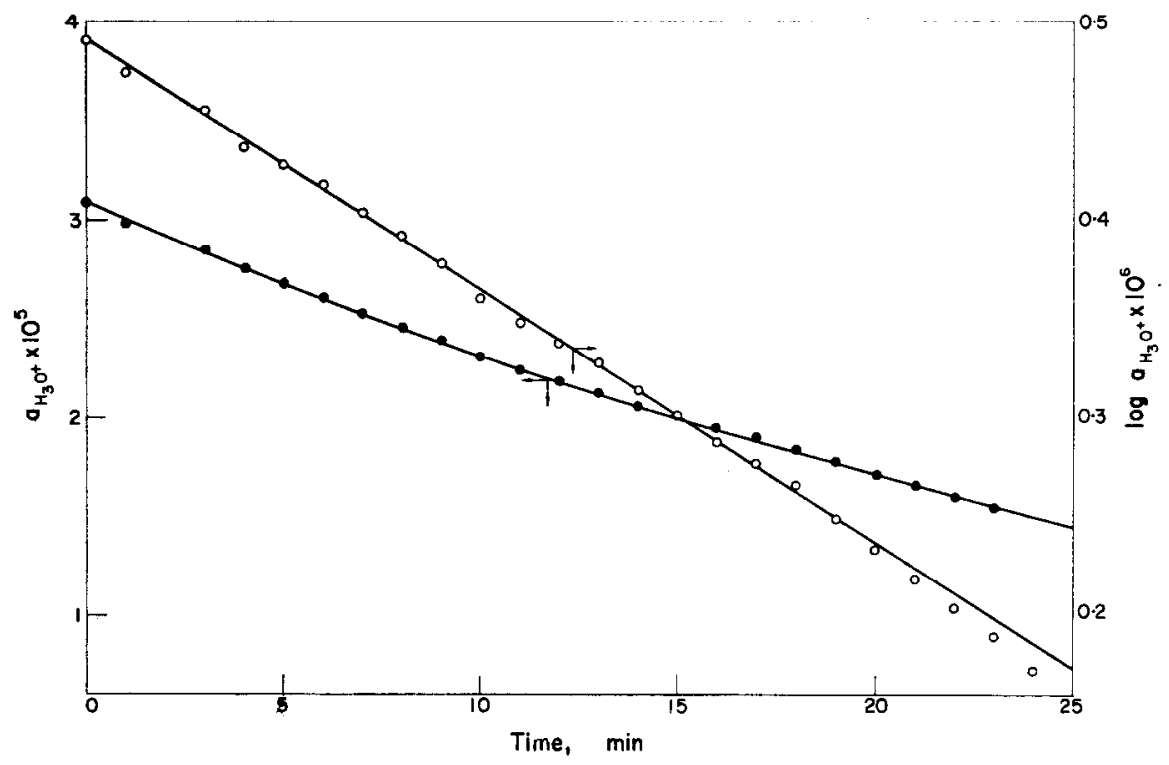

FIG. 1. Decreasing rate of hydrogen-ion activity and plot according to a first order rate equation.

$0.2 \mathrm{M} \mathrm{NaClO}_{4}, \mathrm{pH} 2 \cdot 51,60^{\circ} \mathrm{C}$ (run 45 ).

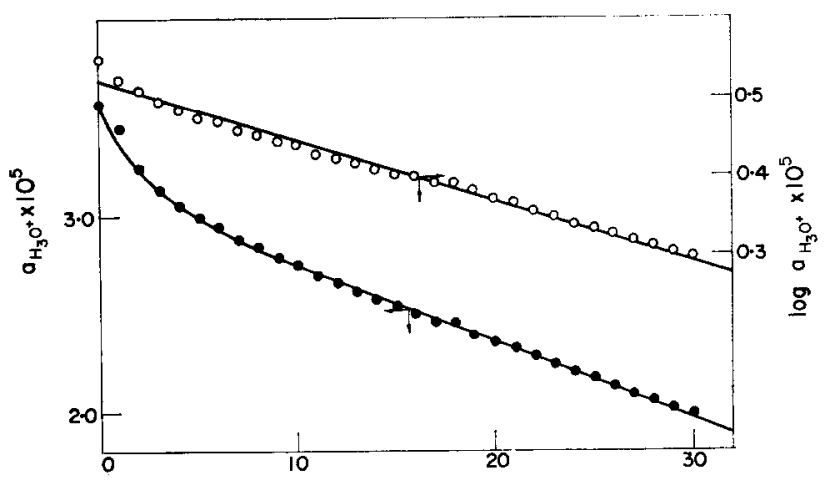

FIG. 2. Decreasing rate of hydrogen-ion activity and plot according to a first order rate equation.

$2 \mathrm{M} \mathrm{NaClO}_{4}, \mathrm{pH} 3 \cdot 95,50^{\circ} \mathrm{C}$ (run 111).

The corrosion current

The corrosion current can be calculated in two ways, either using the kinetic parameters related to the iron-dissolution reaction, or considering the hydrogen-evolution reaction of the metal. If the corrosion electrochemical parameters are known, these calculations must give identical results, provided that the corrosion current density be equal to the partial anodic and cathodic current densities. It is known that the hydrogen-evolution reaction on iron is an activated process related to the discharge of the hydrogen ion, the cathodic current density being given by

$$
\left(i_{\mathrm{corr}}\right)_{c}=k_{c^{z}} z a_{\mathrm{H}^{+}} \exp \left(\eta / b_{c}\right),
$$


where the overpotential $\eta$ is the difference between the corrosion potential, $E_{c}$, and the potential of the hydrogen electrode $E_{\mathrm{H}}$. Both potentials are known functions of $\mathrm{pH}$; $b_{c}$ is the Tafel slope and $k_{c}$ is the specific rate constant for the hydrogen-evolution reaction. The application of equation (1) implies a knowledge of $b_{c}$, equal to $2 R T / F$. $a_{\mathrm{H}^{+}}$is the activity of the hydrogen ion.

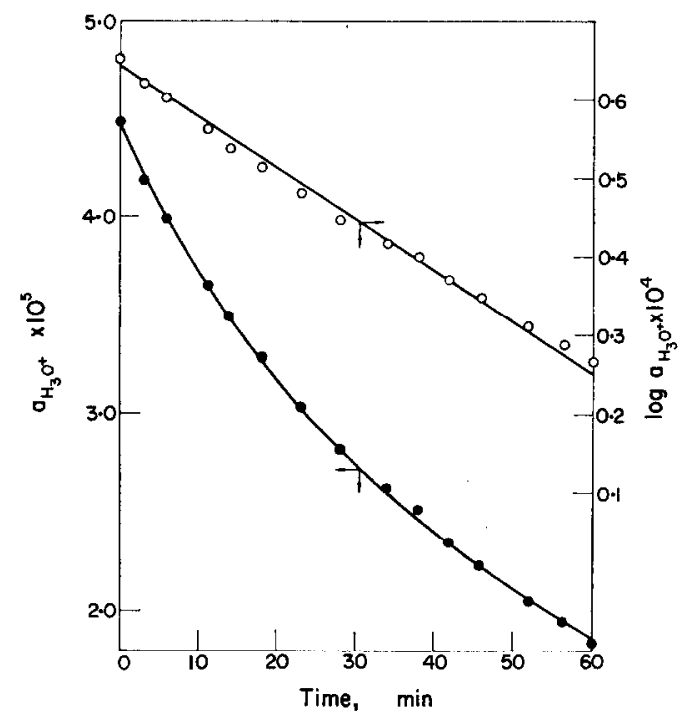

FIG. 3. Decreasing rate of hydrogen-ion activity and plot according to a first order rate equation.

$2 \mathrm{M} \mathrm{NaCl}, \mathrm{pH} 3 \cdot 35,40^{\circ} \mathrm{C}$ (run 85).

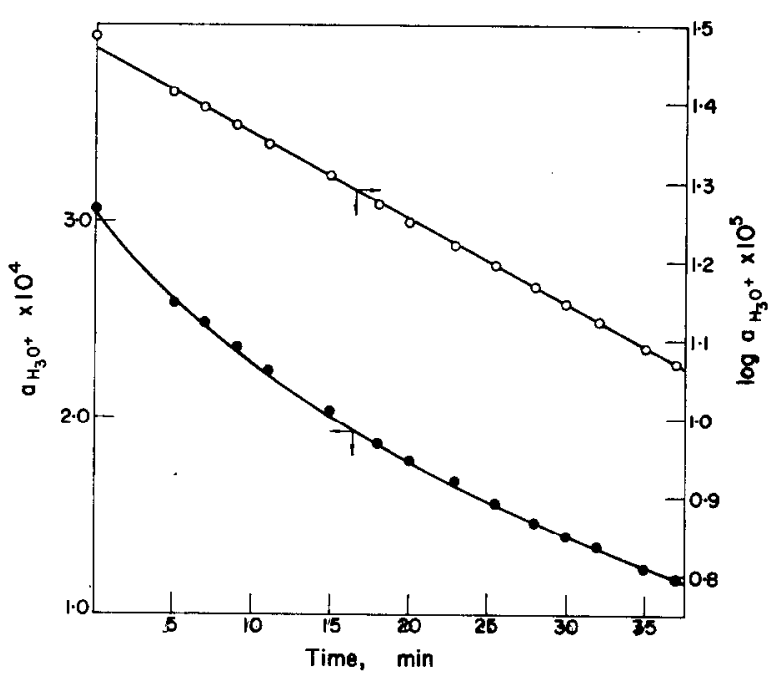

FIG. 4. Decreasing rate of hydrogen-ion activity and plot according to a first order rate equation.

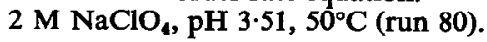




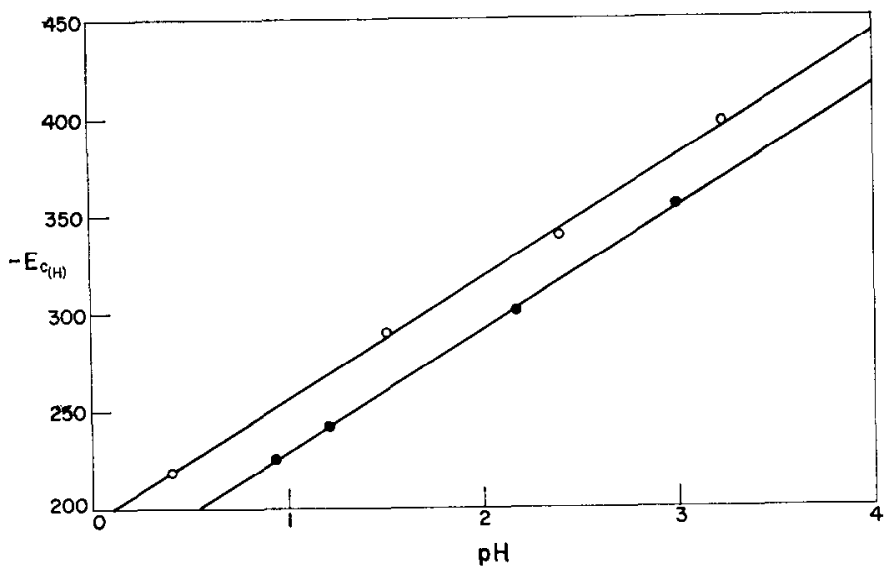

FIG. 5. Corrosion potential us $\mathrm{pH}$.

(•) $2 \mathrm{M} \mathrm{NaClO}_{4},(O) 0 \cdot 2 \mathrm{M} \mathrm{NaCl} 50^{\circ} \mathrm{C}, \delta E_{\mathrm{c}} / \delta \mathrm{pH}=2 \cdot 3(R T / F)$.

\section{The corrosion current and $\mathrm{pH}$}

The results indicate that the corrosion current depends mainly on the $\mathrm{pH}$ of the system and on the nature of the electrolytic solutions, as shown in Figs. 7 and 8. For all cases the corrosion current decreases with $\mathrm{pH}$ in the range $0-4$. The corrosion current is greater for the solutions containing sodium perchlorate and decreases in sodium chloride and sodium nitrate solutions. This fact is not appreciably affected by

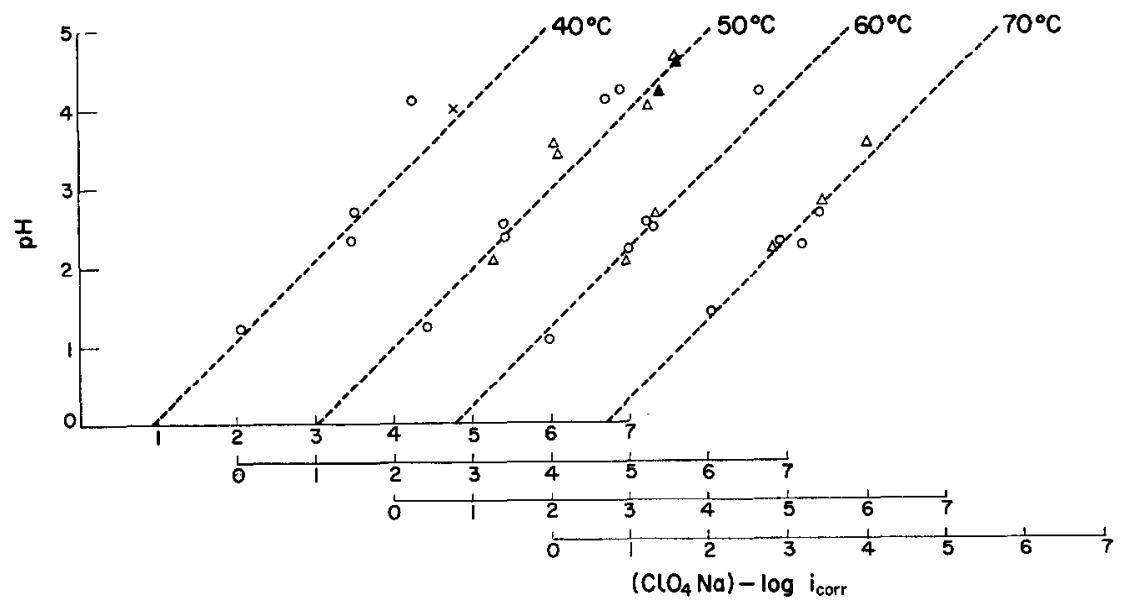

FIG. 6. Dependence of $\log i_{\text {corr }}$ on $\mathrm{pH}$ at different temperatures.

(O) $2 \mathrm{M} \mathrm{NaClO}_{4},(\triangle) 0.2 \mathrm{M} \mathrm{NaClO}_{4},(\Delta) 2 \mathrm{M} \mathrm{NaClO}_{4},(\times) 1 \times 10^{-2} \mathrm{M} \mathrm{Fe}\left(\mathrm{ClO}_{4}\right)_{2}$.

either the concentration of the salt or the presence of ferrous ions. The results are well approximated by the following slopes:

(a) for sodium perchlorate solutions: $\partial \log i_{\mathrm{corr}} / \partial \mathrm{pH}=-1$; and (b) for sodium chloride and sodium nitrate solution: $\partial \log i_{\text {corr }} / \partial \mathrm{pH}=-0.5$.

The corrosion current for sodium perchlorate and sodium chloride solutions reach the same value for a $\mathrm{pH}$ above 4 . The greater differences in the corrosion currents are observed at lower $\mathrm{pH}$, and this fact is independent of the temperature. 


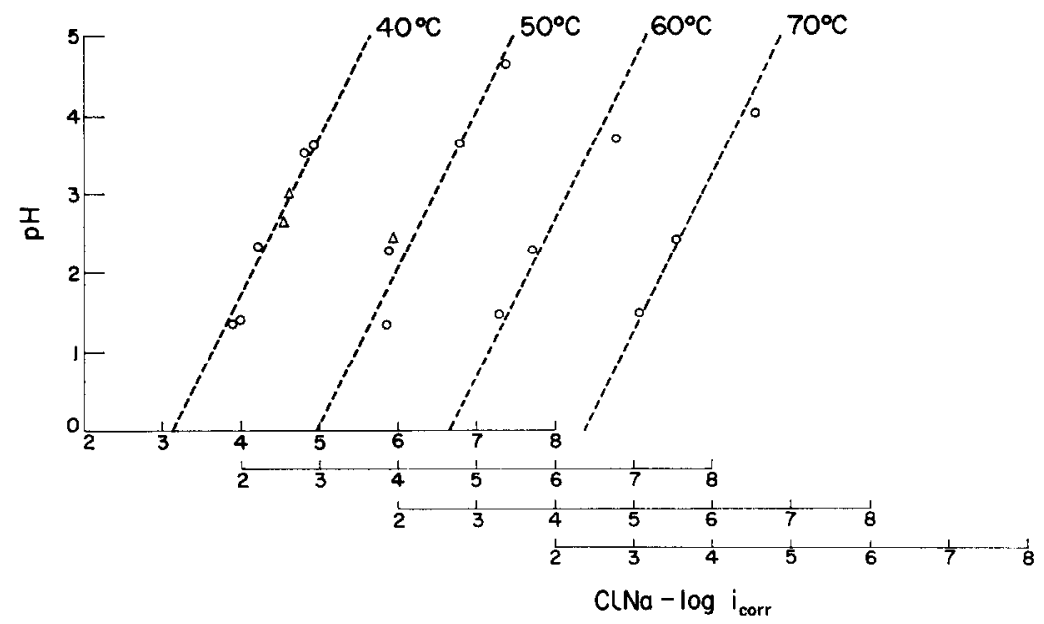

FIG. 7. Dependence of $\log i_{\text {corr }}$ on $\mathrm{pH}$ at different temperatures.

(O) $2 \mathrm{M} \mathrm{NaCl},(\triangle) 0 \cdot 2 \mathrm{M} \mathrm{NaCl}$.

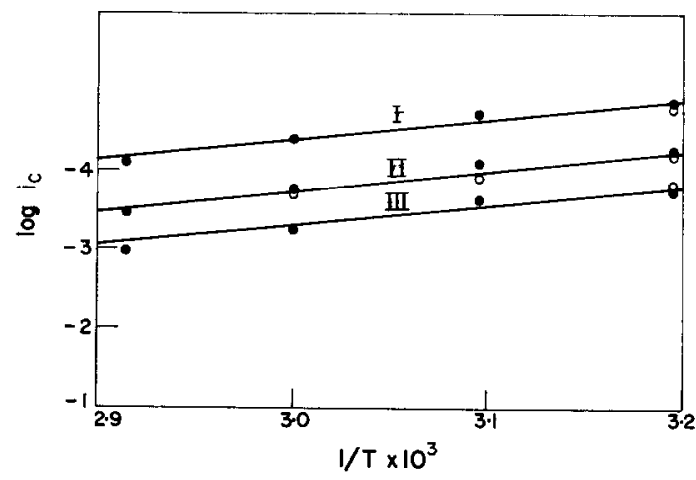

FIG. 8. Arrhenius plot for $2 \mathrm{M} \mathrm{NaCl}$ solutions. I, pH 3.50; II, pH 2.25; III, pH 1.25.

\section{The effect of temperature}

The corrosion current increases as the temperature increases and the relationship between these magnitudes is represented by an Arrhenius plot (Figs. 8 and 9). Experimental heats of activation calculated for the corrosion process occurring in the different ionic media are: $\left(E_{a}\right)_{\mathrm{NaClO}_{4}}=7,900 \mathrm{cal} / \mathrm{mol} \pm 500$, and $\left(E_{a}\right)_{\mathrm{NaCl}}=11,500 \mathrm{cal} / \mathrm{mol}$ \pm 500 .

\section{DISCUSSION}

The rate of dissolution of iron in acid media is related to a potential of the metal, which is $\mathrm{pH}$ dependent. Many authors have discussed the relationship between corrosion potential and $\mathrm{pH}$. Most of the experimental work done in the last years indicates that the corrosion potential decreases by $2 \cdot 3(R T / F) \mathrm{V}$, as the $\mathrm{pH}$ increases by one unil. ${ }^{1-3}$ This dependence fits the different systems up to $\mathrm{pH} 5$. However, D'Ans and Brekheimer ${ }^{4}$ have observed that at low $\mathrm{pH}$, anion concentration affects the corrosion potential. Thus for solutions containing sulphate and chloride ions at the same $\mathrm{pH}$, the corrosion potential is higher for the latter. Recently, Hurlen ${ }^{5,6}$ stated that 
when the ferrous iron concentration is low, the variation of corrosion potential with pH must satisfy a straight line plot with a slope $-\frac{4}{5}(R T / F)$.

The results shown in Fig. 5 agree satisfactorily with most of the available data and with the observation of D'Ans and Brekheimer. The corrosion potential is greater for the solutions containing chloride ion. This different behaviour of the solutions also obtains for the kinetics of iron dissolution in both media.

As a matter of fact, when the metal is corroding at its corrosion potential, the partial anodic current density $i_{a}$ would have to be equal to the cathodic partial current density $i_{c}$ and both equal to the corrosion current density $i_{\text {corr }}$, if the actual areas for both cathodic and anodic processes are the same. Therefore the corrosion current may be calculated independently through the anodic reaction or through the cathodic reaction, but this is possible only if Tafel constants for both processes are known.

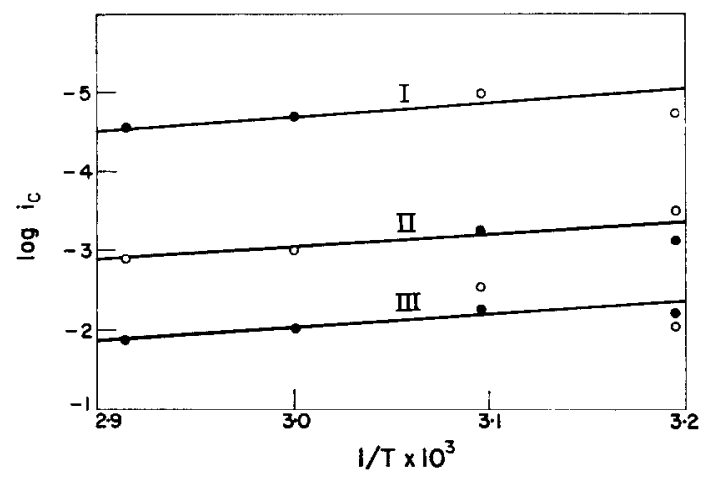

FIG. 9. Arrhenius plot for $2 \mathrm{M} \mathrm{NaClO}_{4}$ solutions. I, pH 4.0; II, pH 2.25; III, pH 1.25 .

To calculate the corrosion current density with the cathodic process data we have taken $b_{c}=2(R T / F)$, a Tafel slope which has been derived as the likely value for hydrogen evolution on iron. ${ }^{7-16}$ The rate-determining step for this reaction is

$$
\mathrm{H}^{+}+\mathrm{H}_{(\mathrm{ad})}+\mathrm{e} \rightarrow \mathrm{H}_{2} \text {. }
$$

It is of interest to consider the same calculation from the anodic reaction. The Tafel slopes for the anodic dissolution of iron are in the range $R T / F^{1,17,18}$ to $\frac{1}{2}(R T / F) .^{6,20}$ However the value given recently by Bockris, Drazic and Despic ${ }^{1}$ has been confirmed in our laboratory through potential/current-density curves and through galvanostatic and potentiostatic measurements. ${ }^{21}$ The average value obtained at different temperatures is $\frac{2}{3}(R T / F)$. Consequently in a first trial this value has been chosen to calculate the corrosion current with the kinetic equation of the anodic reaction. In this case experiments done in the presence of ferrous ion have been particularly taken into account, because this condition permits a more accurate calculation of the reversible potential of the iron electrode. The equation for the corrosion current density including the parameters of the anodic process, based on the scheme of reaction of Bockris, Drazic and Despic, ${ }^{1}$ is

$$
\left(i_{\text {corr }}\right)_{a}=k_{a} z F a_{\mathrm{OH}^{-}} \exp \left(\eta / b_{a}\right) .
$$

In applying equation (2), which involves the specific kinetic constant $k_{a}$ for the anodic dissolution of iron, $k_{a}$ has been taken as twice the kinetic constant corresponding to 
the decrease of hydrogen-ion activity. Equation (2) is based on a mechanism of reaction where the first step is the interaction of a hydroxyl ion with an iron atom of the crystalline lattice. $\eta$ is in this case the difference between the corrosion potential and the reversible potential of the iron electrode. Equations (1) and (2) yield coincident values for $\mathrm{pH}$ beyond 4. At lower $\mathrm{pH}$, the differences are greater. Thus at $\mathrm{pH} 1$ is of the order of $10^{2}$.

When $\left(i_{\text {corr }}\right)_{a}$ is calculated by means of (2) with Tafel slope values $2(R T / F)$ and $\frac{1}{2}(R T / F)$ the figures are much higher or lower than the experimental ones. The same disappointing result appeared when a second order equation with respect to hydroxyl ion for the corrosion current was assumed, as proposed by Heusler. ${ }^{20}$ We must empha-

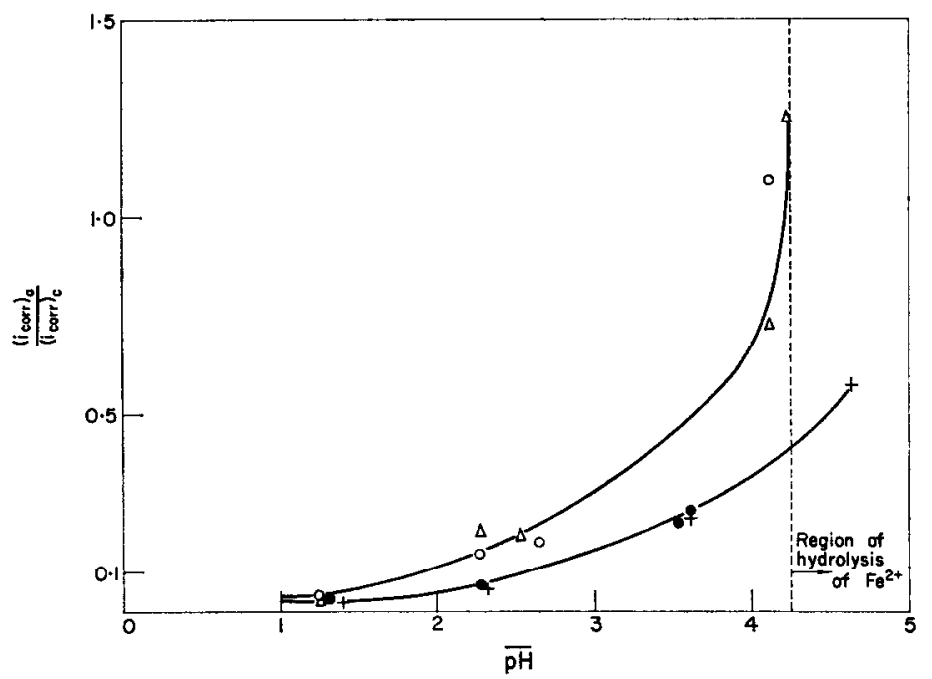

FIG. 10. Ratio of corrosion currents calculated with equations (1) and (2) $v s \mathrm{pH}$. The hydrolysis region of ferrous ion depends on its concentration and has been estimated with data from the literature. ${ }^{19}$

size the fact that the experimental corrosion currents obtained in the present case through (1) agree perfectly with the ones obtained by extrapolation of the currentdensity/potential curves for the anodic dissolution of iron to the corrosion potential of the metal. ${ }^{21}$

To explain the difference of corrosion current densities resulting from (1) and (2) respectively, we must consider the actual surface where both reactions occur. When those equations are applied the kinetic constant for the dissolution of the metal at its corrosion potential is referred to the same area and the discrepancy between calculations suggests the possibility that the actual areas of both cathodic and anodic processes are very different.

If the difference is attributed to the different actual areas of both reactions, the ratio between the corrosion current density from the cathodic reaction and that from the anodic rcaction would give an indication of the ratio between the actual areas involved in both processes (Fig. 10). Consequently, if this is so, it stands to reason that an iron electrode at lower $\mathrm{pH}$ value tends to behave as a hydrogen electrode.

Another related fact is the effect of the anion present in the different ionic media. It 
is clear that the rate of dissolution of iron in the presence of chloride ions is lower than in the presence of perchlorate ions, and the difference increases with decreasing $\mathrm{pH}$.

It is to be noted that Bockris, Drazic and Despic ${ }^{1}$ observed a similar effect on the exchange current density for the iron electrode. At pH 3 in ferrous-perchloratesodium-perchlorate solution the exchange current-density is $50 \times 10^{-8} \mathrm{~A} / \mathrm{cm}^{2}$, while at the same $\mathrm{pH}$, the exchange current-density in ferrous-chloride-potassium-chloride solution is $8 \times 10^{-8} \mathrm{~A} / \mathrm{cm}^{2}$. The same effect should appear in the corrosion currentdensity.

The inhibiting effect of chloride ions for iron dissolution was reported earlier, ${ }^{22}$ and the influence of anions on the rate of metal dissolution has been the subject of special consideration by Kolotyrkin ${ }^{23}$ and Hackerman. ${ }^{2426}$ These authors have observed the effect of specific adsorption on the metal surface of various anions and the change produced in the electrical double layer for some particular cases. On the other hand the adsorption of anions on liquid metallic electrodes has been particularly considered by Grahame and Soderberg, ${ }^{25}$ who showed that chloride ion is adsorbed more strongly than perchlorate ion. Considering the part played by the anions in the process we have studied, the following order of adsorbability could reasonably be established: $\mathrm{OH}^{-}>\mathrm{Cl}^{-}>\mathrm{ClO}_{4}^{-}$. According to Bockris, Drazic and Despic, the iron dissolution reaction requires interaction of hydroxyl ions with iron atoms. At low $\mathrm{pH}$ it is reasonable to assume that the amount of adsorbed hydroxyl ions is low. The presence of chloride ions would have the effect, especially when the concentration is high, of decreasing the actual metal area available for the anodic process. When the hydroxyl ion concentration is increased, the amount adsorbed would also increase and when the region of the hydrolysis of $\mathrm{Fe}_{\mathrm{aq}}{ }^{2+}$ ion is reached, those ions would prevail on the coverage of the metal surface. This could account for the following effects that were experimentally observed: (a) a shift of the metal potential from its behaviour as a hydrogen-type electrode, (b) the rate of dissolution is unaffected by the type of anions present in the system and (c) the cathodic and anodic area tend to the same value, both reactions occurring at random on the metal surface.

\section{The effect of $\mathrm{pH}$ on the corrosion rate}

The effect of $\mathrm{pH}$ on corrosion rate is shown in Figs. 6 and 7. The slopes of the straight lines which approximate the results are not apparently affected either by temperature or by the presence of different concentrations of ferrous ion. If we consider the kinetic equation for hydrogen evolution on iron, taking into account that Tafel slope is $2(R T / F)$, and also considering that both the corrosion and the hydrogen electrode potentials are known functions of the $\mathrm{pH}$, a slope of -1 should be obtained from a plot of $\log i_{c} v s \mathrm{pH}$. This is precisely what is found in the case of sodium perchlorate solutions.

Experimental data for sodium chloride solutions give a slope of about $-0 \cdot 50$. A similar slope was obtained for the corrosion current densities obtained from Tafel lines extrapolated to the corrosion potential by other authors, ${ }^{1}$ who employed sodium sulphate solutions. However, according to the value of the Tafel slope in the corresponding kinetic equation for the iron dissolution process, a slope between -0.50 and -0.60 should result by plotting $\log i_{c} v s \mathrm{pH}$.

Nevertheless, as the actual anodic and cathodic areas might be different and the difference between them is a function of $\mathrm{pH}$, the slope in Figs. 6 and 7 is probably due 
to a more complex relationship. Hence a further detailed discussion of the $\mathrm{pH}$ dependence of corrosion current requires a sounder knowledge of Tafel slope for iron dissolution, related to the specific behaviour of the different anions.

\section{The heat of activation}

The heats of activation is independent from $\mathrm{pH}$ but changes with the nature of the electrolyte. For solutions containing chloride ions, the heat of activation $\Gamma$ is certainly greater than that for perchlorate solutions. If specific adsorption occurs, iron dissolution must take place through a reaction involving the desorption of chloride ions, and therefore the energy of activation would be different from that observed in its absence. We may therefore suggest that the difference between the energies of activation may be related to the adsorption energy of chloride ions as compared to the system containing perchlorate ions.

Acknowledgement-We thank Dr T. P. Hoar for his advice on the presentation of this paper. The work was done with financial support of Comisión de Investigación Científica de la Provincia de Buenos Aires and Consejo Nacional de investigaciones Científicas y Tecnicas de la Argentina.

\section{REFERENCES}

1. J. O'M. Bockris, D. Drazic and A. R. Despic, Electrochim. Acta 4, 325 (1961).

2. H. KAESCHE, Z. Elektrochem. 63, 492 (1959).

3. K. F. BonhoEfFer and K. E. Heusler, $Z$. phys. Chem. 8, 390 (1956).

4. J. D'ANS and W. BRECKHEIMER, Z. Elektrochem. 56, 585 (1952).

5. T. Hurlen, Acta Chem. Scand. 14, 1555 (1960).

6. T. Hurlen, Acta Chem. Scand. 14, 1533 (1960).

7. R. Parsons, Trans. Faraday Soc. 54, 1053 (1958).

8. J. O'M. BockrIs, Modern Aspects of Electrochemistry, Vol. I, Chap. IV. Butterworths, London (1954).

9. T. P. HoAr and T. Hurlen, Proc. 8th Meeting CITCE, Madrid, 1956. Butterworths, London (1958).

10. T. HuRLEN, Tek. Ukeblad 105, 101 (1958).

11. K. F. BonhoefFer and K. E. HeUSLer, Z. phys. Chem. 8, 390 (1956).

12. K. F. BONHOEFFER and K. E. HeUSLER, $Z$. Elektrochem. 61, 122 (1957).

13. M. STERN, J. Electrochem. Soc. 102, 609 (1955).

14. M. STERN, J. Electrochem. Soc. 102, 663 (1955).

15. H. FisCher and G. ThORESEN, $Z$. Elektrochem. 62, 235 (1958).

16. R. PARsons, Trans. Faraday Soc. 47, 1332 (1951).

17. M. STERN and R. M. Roth, J. Electrochem. Soc. 104, 390 (1957).

18. A. C. MAKRIDES, J. Electrochem. Soc. 107, 869 (1960).

19. J. A. Bolż́n and A. J. ARvíA, Electrochim. Acta 8, 375 (1963).

20. K. E. Heusler, $Z$. Elektrochem. 62, 582 (1958).

21. J. J. Podestá and A. J. Arvía, Electrochim. Acta 10, 171 (1965).

22. G. WALPERT, $Z$. phys. Chem. A151, 219 (1930).

23. JA. M. Kolotyrkin, J. Electrochem. Soc. 108, 209 (1961).

24. P. V. Popat and N. Hackerman, J. Phys. Chem. 62, 1198 (1958).

25. D. Grahame and D. A. Soderberg, J. Chem. Phys. 22, 449 (1954).

26. G. M. Schmid and N. Hackerman, J. Electrochem. Soc, 107, 647 (1959). 